\title{
CUSTOMER ENGAGEMENT WITH A BRAND IN THE CONTEXT OF SOCIAL MEDIA
}

\author{
Magdalena Hofman-Kohlmeyer ${ }^{1}$
}

\begin{abstract}
Nowadays, a strong brand is one of the most valuable assets of a company. In order to obtain this asset, the growing ranks of enterprises decide to include social media in their marketing strategy. Social media gives the possibility to have customers highly engaged with a brand. The present article is aimed to give an outlook on the process of building customer engagement in a brand throughout social media. The presented approach is based on a literature review.
\end{abstract}

INTRODUCTION: The meaning of social media in engaging customers is widely acknowledged. In order to building a strong brand and make current customers loyal, the growing ranks of managers decide to include social media in their marketing strategy.

OBJECTIVES: The present article is aimed to give a theoretical outlook on engaging a customer with a brand throughout social media.

METHODS: To achieve the assumed goals the author presents a literature review.

RESULTS: The literature review offers some directives on how to make customer engage with a brand, information on how this process should proceed and information about the profits which can the brand obtain.

CONCLUSION: Social media gives an opportunity to make customers highly engaged in a brand. The building of customer engagement throughout social media takes place through the following process: connection, interaction, satisfaction, retention, commitment, advocacy and customer engagement. Social media is also treated as a source of mass communication. One-toone communication between stakeholders and firm-to-firm communication exert a positive impact on brand trust. In terms of customer-to-customer communication, there are some doubts. The authors also indicated the vital role of content quality and the occurrence of negative conversations on the fan page.

JEL Classification Numbers: M31; DOI: http://dx.doi.org/10.12955/cbup.v5.920

Keywords: customer engagement, social media, brand

\section{Introduction}

Since the emergence of the commercial internet, spending on online advertising campaigns have been continuously growing. The internet has quickly become a strong competitor of other communication channels. Online advertisement makes users involved, enhance them to interact and increase their interest in a product or service (Dudzik-Lewicka \& Hofman-Kohlmeyer, 2015). On the internet, the line between entertainment and advertising become blurred (An, Stern, 2011). Within the last couple of years, online promotion has undergone many changes. One of the developed means of communication is contextual advertisement. It allows to reach consumers at the exact time while they watch the contents substantially related to the product or service promoted (Dudzik-Lewicka \& Hofman-Kohlmeyer, 2015). There is recognition of increase in use of social media among corporations. According to the University of Massachusetts Dartmouth, in 2012, 73\% of companies among Fortune 500 had an official profile on Twitter, and $66 \%$ had a page on Facebook. Furthermore, social media goes to mobile, mitigating the traditional time-location restrictions (Okazaki \& Taylor, 2013). In a relatively short period of time, managers have included social media for a variety of marketing purposes, e. g. branding, research, customer relationship management, service, sales promotions. The most important purpose is using social media for branding, as an integrated component in marketing communications channel (Ashley \& Tuten, 2015). The interactivity of social media enables users to establish conversations with individuals and firms in communities of sellers and customers. Customers are involved in the content generation, and value creation and practitioners have the possibility to serve customers better and meet their needs.

The evolution of the internet was timed to coincide with the increasing interest in customer engagement (Sashi, 2012). Some authors defined engagement in the context of a psychological state, while others focus on its behavioral manifestations toward a brand or a company (Cabiddu et al., 2014). There is an approach to customer engagement that assumes that engagement is a tendency to maintain a relationship with a partner, even when the delivered value does not meet expectations, and there is the small prospect of any change in the future (Mitręga, 2005). New ways to engage both firms and customers with each other in social media is a brand community with a large number of users (Gummerus et al., 2012). Although the importance of social media for customer engagement is acknowledged, a better

\footnotetext{
${ }^{1}$ University of Economics in Katowice, Faculty of Informatics and Communication, magda-hofman @ o2.pl
} 
understanding of this phenomenon can help find the unique features of social media (Cabiddu et al., 2014).

This article is organized as follows. At first, the role of the brand is presented. The next part constitutes the characterization of customer engagement in a brand through the social media based on a literature review. In the final part, there are some suggestions for future research and the conclusion. The role of the brand

Contemporary organizations develop a variety of methods to build a strong brand as part of their business strategy. The brand is often evaluated as a company's most valuable asset (Wallström et al. 2008). A customer which is loyal to the brand may be willing to pay more for the product with the brand's logotype because they perceive some unique value. The uniqueness may be caused by grater trust in the reliability of a brand (Chaudhuri \& Holbrook, 2001).

Brand building activities are positively correlated with brand equity and lead to acquiring and retaining customers and increasing the value for a company. Brand equity is important in building long lasting relationships with customers (Samu et al., 2012). Brand equity is a set of brand assets and liabilities linked to a brand, its name and symbol that add or subtract from the value provided by a product or service to a firm and/or to that firm's customer.

The brand effect and brand trust are positively related to brand commitment (Chaudhuri \& Holbrook, 2001). Commitment is defined as the customer's confidence that the functional and affective benefits from maintaining a relationship with the companies are greater than the benefits from ending them. Commitment is described as a core feature of customer relationship management and an inevitable factor in achieving a company's goals. Customer committed to a brand is motivated by company to actively cooperate with customers and not to choose competitors' offer (Hur et al., 2011).

The popularity of social media enabled companies to build close relationships between their customers and themselves (Cabiddu et al., 2014). Branded social campaigns can be utilized to increase brand awareness and brand liking, enhance customer engagement and loyalty, and evoke consumer word-ofmouth communication about the brand (Ashley \& Tuten, 201). Nowadays, a vast number of Polish firms treat building the relationship with customers as the most important part of the marketing strategy (Mitrega, 2006).

\section{Customer engagement with a brand and social media}

In recent years, the emergence of new digital technologies and tools can be observed, especially social media like blogs, micro blogging sites like Twitter, video sites like YouTube, virtual worlds like Second Life and social networking sites like Facebook, MySpace or LinkedIn (Sashi, 2012). Cabiddu et al. (2014) reminded that social media are defined as a group of Internet based applications which build on the ideological and technological foundations of Web 2.0 and which allow the creation and exchange of user-generated content. Social media contain applications that allow users to create, edit and access content and communicate with other individuals (Cabiddu et al., 2014). The growing popularity of social media led to the necessity of better understanding these technologies and tools especially as an opportunity for creating customer engagement. Customer engagement focuses on satisfying customers by providing better value than competitors in order to gain customers' trust and commitment in longterm relationships. The interactivity of social media enhances the process of creating relationships between sellers and buyers (Sashi, 2012).

Sashi (2012) examined customer engagement from the point of view of the practitioners. He formulated a customer engagement cycle with the following stages: connection, interaction, satisfaction, retention, commitment, advocacy and engagement. The cycle is presented in Figure 1.

Connection is the first step to establish emotional bonds between sellers and buyers. To connect with the buyers, a company can use simultaneously traditional offline methods (e. g. a salesperson) as well as new digital online methods (e. g. social networking). Social media expedites the establishment of connection with a large number and wide variety of individuals and firms.

Interaction is the second stage in the cycle. The growth of the internet mitigated the restrictions in communication like space and time 


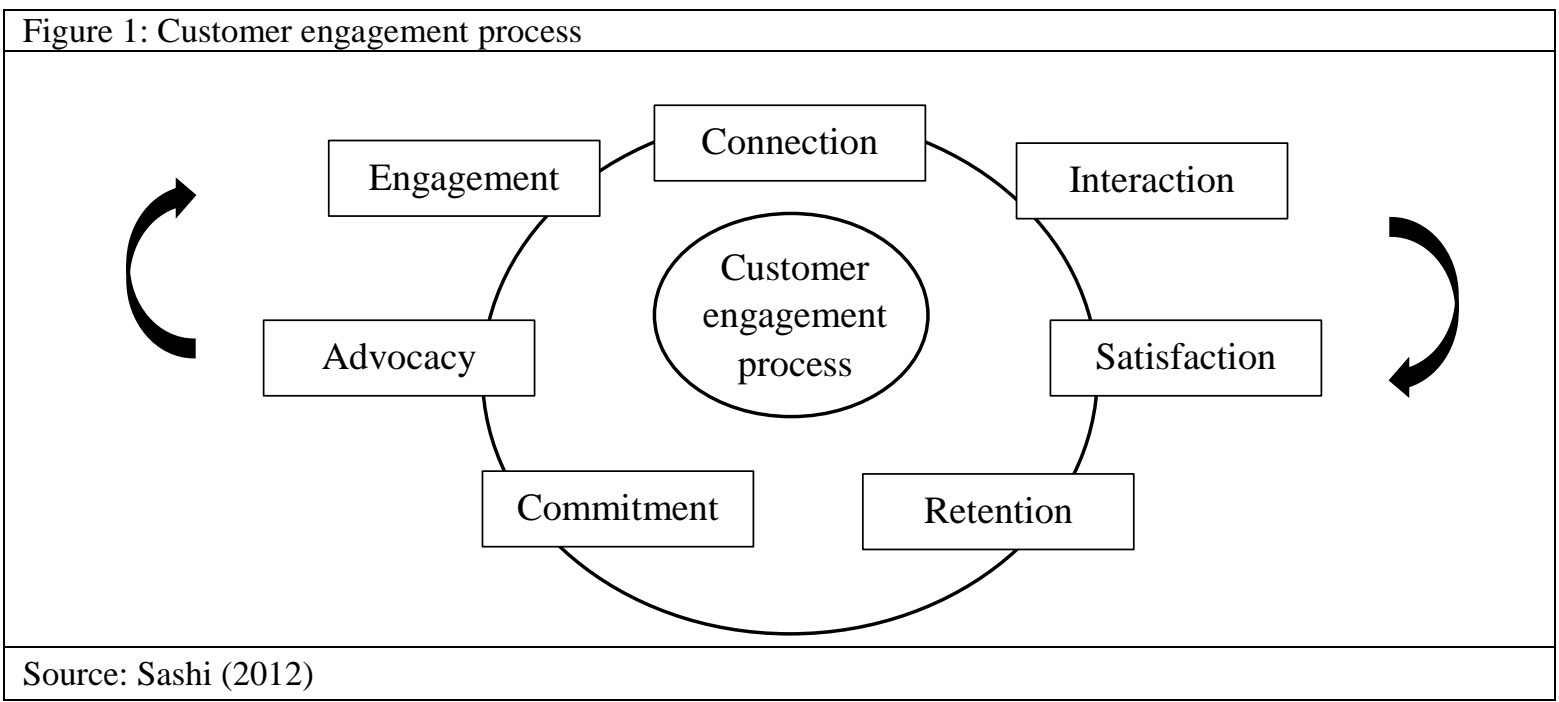

Worldwide interactions among people at real time have become possible through social networking, virtual worlds or instant messaging. Interactions between companies and their customers can improve the understanding of customer needs and help upgrade existing products or develop new products to better meet these needs. The Internet allows marketers to maintain a dialogue with customers. This dialogue can support research and development activities, involve customers in new product development and in market testing stages, and allow for the companies to understand customers' needs. Customers can collaborate with marketers and participate in the value adding process.

Satisfaction is necessary to maintain connection between a company and its customer and to make progress towards engagement. Satisfaction is an intermediate step to achieve the goals of an organization. It is an inevitable but not sufficient condition for customer engagement. Satisfaction can be defined as an overall evaluation based on the total purchase and consumption experience of goods or services over time. Satisfaction is achieved at a high level when the company exceeds the customer's expectation and the customer's emotions are highly positive.

Customer retention is an expected result from satisfaction and positive emotions. Retention leads to repurchases and implies a long-term relationship between customers and a brand.

Commitment in a relationship can be considered in two dimensions: effective commitment and calculative commitment.

Calculative commitment is rather rational and often is caused by a lack of another choice or switching costs. Affective commitment is rather emotional and is the effect of the trust and reciprocity in a relationship. Affective commitment can build a higher level of emotional bond between the customer and seller.

Advocacy occurs when satisfied customers spread the word about their positive experiences with a product, brand or company using their Internet social networks. Customers offer some recommendations to another using word-of-mouth communication. Affective commitment is positively related to advocacy, and calculative commitment is not. Companies can play advocacy roles as well as customers by acting in the customers' best interest. Companies expect that they will look after each other with and the customers and the values will be exchanged.

Engagement can happen when customers are loyal and delighted, share their experiences with other's in their social networks and become advocates for a product, brand or company. To achieve customer engagement, a company need to create strong emotional bonds with customers. Customer engagement includes customers in the creation of value, enhances their satisfaction and turns customers into fans.

The customer in each stage of the cycle can be arrayed in a customer engagement matrix (Figure 2). Transactional customers are distinguished by low emotional bonds and low relational exchange. They are price sensitive and switching sellers from transaction to transaction. These customers are the source of customers for the other cells in the array. A company can potentially turn these customers into loyal, delighted customers or fans.

We have delighted customers when the relational exchange is low and emotional bonds are high. 
Delight does not cause long-term relationship. The company needs to enhance relational exchange.

Figure 2: Customer engagement matrix

\begin{tabular}{|c|c|c|c|}
\hline \multirow{3}{*}{$\begin{array}{l}\text { Emotional } \\
\text { Bonds }\end{array}$} & High & $\begin{array}{l}\text { Delighted } \\
\text { Customers }\end{array}$ & Fans \\
\hline & Low & $\begin{array}{c}\text { Transactional } \\
\text { Customers }\end{array}$ & $\begin{array}{c}\text { Loyal } \\
\text { Customers }\end{array}$ \\
\hline & & Low & High \\
\hline
\end{tabular}

Source: Sashi (2012)

Loyal customers are characterized by high relational exchange and low emotional bonds. Customers are loyal only for rational reasons. There is lack of emotional connections between the customers and the brand. According to future intentions, there is a need for developing effective commitment and turn loyal customers into fans.

When customers are fans, we have customer engagement. Relational exchange and emotional bonds are high. Fans trust companies and advocate for them. They connect with other fans and interact with them.

Companies want to have many customers who are fans and also delighted, loyal and transactional customers who can be future fans. This process can be improved by using social media, especially when it comes to establishing connections, interactions, and the increasing likelihood of satisfaction. Social media enhance deriving of transactional customers, creating delighted and loyal customers and turning them into fans (Sashi, 2012).

Vohra \& Bhardwaj (2016) carried out a research study in the field of social media and customer engagement in a brand. They focused on Twitter and Facebook because these two platforms were on the top of the list of social media channels being used by marketers for engagement. A questionnaire with open-ended questions was sent by e-mail to digital media managers of 25 firms in India. The survey reveals how firms view engagement in the context of social media.

According to the study, social media channels offer a wide range of features which the brands can use to engage with their customers. Managers indicate the potential of social media as a source of mass communication, one-to-one communication between stakeholders and also firm-to-firm and customerto-customer communication. Marketers focus on behavioral dimensions of engagement, like some customers' activities, for example sharing the company's content and posts with the others participating in the conversations. Many customers are not active users, but they are engaged in brand passively. Customers may use information shared on social media in an active and frequently way, without taking part in any conversations. Customers must be attracted to a brand's social media by the content. The content should invite customers to conversations and attract the passive customer. Content can take the form of a simple text, videos, audio clips, or images. Social media can be used as a social recommendation system (like and share buttons). Managers should take into consideration that conversations can be positive but can be negative too. Many customers use social media profiles to express their negative feelings towards the brand. These negative conversations can lead to negative engagement. It is important to marketers to manage positive as well as negative conversations that take place on social media (Vohra \& Bhardwaj, 2016).

Habibi et al. (2014) investigated the process of building brand trust in social media, especially in brand communities. They conducted a survey of members of the brand community. Participants filled out a questionnaire. The findings provide information on how brand community and engagement in social media impact building brand trust.

The brand community relationship such as customer-brand, customer-product and customer-company positively influence brand trust. Surprisingly, the customer-other customer relationship exerts a negative 
influence on brand trust. Perhaps some members have doubts about the credibility of the received informations from social media. Another explanation assumed that consumers' connectivity and interactions increase customers' expectations toward the brand. We can suspect that the brands have limited control of social media. On the top of that, the literature review offers mixed results in this issue. The research conducted by Habibi et al. also support the statement that community engagement matters in social media. Engaging consumers in brand communities creates a stronger relationship with the brand, the product, other consumers and the company. Conversely, consumers who trust the brand, more willingly participate in the brand community and building of the brand relationship (Habibi et al., 2014).

Although the importance of social media for customer engagement in a brand is acknowledged, there are some suggestions for further research in the literature review. In future research Laroche et al. (2013) recommended to utilize a brand type, culture, characteristics and facilities of the community on social media to examine how these variables affect customer relationships with brand elements (Laroche et al., 2013). Kim \& Ko (2012) indicated that a future study should develop effective tools to measure appropriately the effect of social media marketing (Kim \& Ko, 2012).

\section{Conclusion}

In recent years, the use of social media among corporations has significantly increased. Managers include social media for marketing purposes like research, customer relationship management, service, sales promotions and especially for branding. Companies have the opportunity to engage customers and maintain the relationship. The building of customer engagement throughout social media takes place according to the previously mentioned cycle. This process begins with the establishment of connection. Next there is interaction, then satisfaction, retention, commitment, advocacy and the final part constitutes customer engagement. This cycle delivers transactional customers, creating delighted and loyal customers and turning them into fans.

Managers indicate the potential of social media as a source of mass communication, one-to-one communication between stakeholders and also firm-to-firm and customer-to-customer communication. These relationships have a positive impact on brand trust, except the customer-to-customer communication. There are various different results present in the studied literature and because of this, additional research might be necessary.

The authors also indicated the vital role of content quality. The content should invite customers to conversations and attract the passive customer. Managers should also take into consideration the negative conversations on fan pages and mitigate the effects of these conversations.

Despite the progress made, there is still a need for further research in this field. A better understanding of the importance of social media for customer engagement can help identify unique features and create better tools to make customers loyal to the brand.

\section{References}

An, S., \& Stern, S. (2011). MITIGATING THE EFFECTS OF ADVERGAMES ON CHILDREN. Journal of Advertising, 40(1), 43-56. Retrieved from https://search.proquest.com/docview/857424261 ?accountid=45580

Ashley, C., \& Tuten, T. (2015). Creative strategies in social media marketing: An exploratory study of branded social content and consumer engagement. Psychology \& Marketing, 32(1), 15. Retrieved from https://search.proquest.com/docview/1636484721 ?accountid=45580

Cabiddu, F., De Carlo, M., \& Piccoli, G. (2014). Social media affordances: Enabling customer engagement. Annals of Tourism Research, 48, 175-192. http://dx.doi.org/10.1016/j.annals.2014.06.003

Chaudhuri, A., \& Holbrook M. B. (2001). The chain of effects from brand trust and brand affect to brand performance: the role of brand loyalty. Journal of marketing, 65(2), 81-93. Retrieved from https://search.proquest.com/docview/227777217?accountid=45580

Dudzik-Lewicka, I., \& Hofman-Kohlmeyer, M. (2015). Effective on-line advertisement of an enterprise - directions of changes. Current problems in management, ed. A. Barcik, H. Howaniec, Z. Malara, University of Bielsko-Biała, 241-254.

Gummerus, J., Liljander, V., Weman, E., \& Pihlström, M. (2012). Customer engagement in a Facebook brand community. Management Research Review, 35(9), 857-877. DOI 10.1108/01409171211256578

Habibi, M. R., Laroche, M., \& Richard, M. O. (2014). The roles of brand community and community engagement in building brand trust on social media. Computers in Human Behavior, 37, 152-161. http://dx.doi.org/10.1016/j.chb.2014.04.016

Kim, A. J., \& Ko, E. (2012). Do social media marketing activities enhance customer equity? An empirical study of luxury fashion brand. Journal of Business Research, 65(10), 1480-1486. doi:10.1016/j.jbusres.2011.10.014 
Laroche, M., Habibi, M. R., \& Richard, M. O. (2013). To be or not to be in social media: How brand loyalty is affected by social media? International Journal of Information Management, 33(1), 76-82.

http://dx.doi.org/10.1016/j.ijinfomgt.2012.07.003

Mitręga, M. (2005). Pomiar relacji pomiędzy przedsiębiorstwem a konsumentem, Marketing i Rynek(2), 2-7. Retrieved from http://bazekon.icm.edu.pl/bazekon/element/bwmeta1.element.ekon-element-000150159908

Mitrega, M. (2006). Building strong relationships between services' providers and consumers: Evidence from Poland. Transformations in Business \& Economics, 5(2), 148-162. Retrieved from http://www.transformations.khf.vu.lt/

Okazaki, S., \& Taylor, C. R. (2013). Social media and international advertising: theoretical challenges and future directions. International marketing review, 30(1), 56-71. DOI 10.1108/02651331311298573

Samu S., Krishnan Lyndem P., \& Litz R. A. (2012). Impact of brand-building activities and retailer-based brand equity on retailer brand communities. European Journal of Marketing, 46(11/12). doi:http://dx.doi.org/10.1108/03090561211259998

Sashi, C. M. (2012). Customer engagement, buyer-seller relationships, and social media. Management decision, 50(2), 253272. DOI $10.1108 / 00251741211203551$

Vohra, A., \& Bhardwaj, N. (2016). A conceptual presentation of customer engagement in the context of social media-An emerging market perspective. International Journal in Management and Social Science, 4(1), p. 351-366. Retrieved from https://www.researchgate.net/profile/Neha_Bhardwaj13/publication

Wallström Å., Karlsson T., Salehi-Sangari E. (2008). Building a corporate brand: The internal brand building process in Swedish service firms. Journal of Brand Management, 16(1-2). doi:http://dx.doi.org/10.1057/bm.2008.18

Won-Moo Hur, Kwang-Ho, A., \& Kim, M. (2011). Building brand loyalty through managing brand community commitment. Management Decision, 49(7), 1194-1213. doi:http://dx.doi.org/10.1108/00251741111151217 